CLINICAL STUDY

\title{
Raloxifene decreases serum IGF-I in male patients with active acromegaly
}

\author{
Eleni V Dimaraki, Kathleen V Symons and Ariel L Barkan \\ Department of Internal Medicine, Division of Endocrinology and Metabolism, University of Michigan and the Department of Veterans Affairs Medical \\ Center, Ann Arbor, Michigan 48109, USA
}

(Correspondence should be addressed to A L Barkan, 3920 Taubman Center, Box 0354, Ann Arbor, Michigan 48109, USA;

Email: abarkan@umich.edu)

\begin{abstract}
Objective: Most patients with acromegaly require additional treatments after trans-sphenoidal surgery. Although traditional methods of treatment aim at suppressing GH hypersecretion from the pituitary tumor, recent studies on the use of the $\mathrm{GH}$ receptor antagonist have shown that targeting the action of $\mathrm{GH}$ on peripheral tissues may be more effective. Estrogens and the selective estrogen receptor modulator tamoxifen have been used previously to suppress circulating IGF-I levels in patients with acromegaly. Positive effects of raloxifene in women with active acromegaly have been reported recently. This study was designed to examine the potential role of raloxifene in the treatment of acromegaly in male patients.

Design: We studied eight men with active acromegaly despite the fact that they were receiving traditional treatments. All subjects were treated with raloxifene $(60 \mathrm{mg}$ twice a day) for a median of 5 weeks.

Methods: The effects of raloxifene on GH secretion were assessed by obtaining 24-h GH profiles and studying the response of $\mathrm{GH}$ to various stimuli before and after treatment with raloxifene. Serum IGF-I was measured before and after raloxifene treatment.

Results: Raloxifene did not affect basal GH secretion or response of GH to TRH, GHRH or glucose, but it decreased circulating IGF-I by $16 \pm 4 \%(P=0.001)$, and normalized plasma IGF-I in two patients. No changes in clinical parameters were observed. Prolactin levels, the prolactin response to TRH and free testosterone levels remained unchanged. Raloxifene was well tolerated.

Conclusion: Raloxifene might be useful in the treatment of male patients with active acromegaly, but longer term studies are clearly needed.
\end{abstract}

European Journal of Endocrinology 150 481-487

\section{Introduction}

Traditionally, treatment of acromegaly is directed at the pituitary tumor with the goal of normalization of growth hormone (GH) hypersecretion. Trans-sphenoidal surgery (TSS), radiotherapy, dopamine agonists and somatostatin analogs all have less than $100 \%$ efficacy $(1-4)$, and significant adverse effects.

Plasma insulin-like growth factor-I (IGF-I) is now considered a sensitive and specific diagnostic marker of acromegaly and has become the gold-standard test in following its activity (5-8). Normalization of plasma IGF-I by the GH antagonist pegvisomant resulted in clinical improvement $(9,10)$, demonstrating that targeting the $\mathrm{GH}$ action and IGF-I production instead of the GH secretion by the tumor is both safe and effective. However, pegvisomant needs to be administered parenterally and is very expensive.
Long before a GH antagonist became available, estrogens and the selective estrogen receptor modulator (SERM) tamoxifen were used to block the action of GH and suppress plasma IGF-I levels (11-16). Both suppress IGF-I production in vitro and in vivo in humans $(17-22)$. In patients with acromegaly, estrogens and tamoxifen suppressed IGF-I by $55 \%$ and $45 \%$ respectively $(14,16,23)$ and, in some studies, the IGF-I suppression was accompanied by clinical improvement.

The newer SERM raloxifene has a more favorable safety profile than estrogen or tamoxifen and has been shown to decrease IGF-I in healthy women and in women with acromegaly $(24-26)$. However, its safety and efficacy profiles have not been tested in men with acromegaly. This study was designed to examine the safety and efficacy of raloxifene in male patients with acromegaly. 


\section{Subjects and methods}

\section{Subjects}

The study was performed at the General Clinical Research Center (GCRC) of the University of Michigan. It was approved by the Institutional Review Board of the University of Michigan. We studied eight Caucasian men with active acromegaly (age 34-63 years, median 41.5 years). All patients signed the informed consent document prior to their participation in the study. All subjects had had TSS that failed to normalize serum IGF-I levels $1-18$ years (median 4 years) prior to their enrollment. Two patients had been on octreotide LAR (Long Acting Release) for more than 6 months prior to their enrollment without normalization of their IGF-I levels and they continued on the same dose of octreotide LAR for the duration of the study. Three patients had at least one anterior pituitary hormone deficiency and one patient had diabetes insipidus. Patients with pituitary hormone deficiencies were on appropriate hormone replacement that was not changed during their participation in the study. Two patients were on testosterone replacement therapy.

\section{Study design}

All subjects received raloxifene ( $60 \mathrm{mg}$ twice a day) for 3.3-6.0 weeks (median 5 weeks). Raloxifene (Evista) was a gift from Lilly (Indianapolis, IN, USA). Seven out of eight subjects were admitted to the GCRC twice, prior to and at the end of raloxifene treatment. Another subject had only serum IGF-I measured before and during treatment with raloxifene. Each subject was admitted to the GCRC at $1700 \mathrm{~h}$ on day 1 . Before any invasive procedures, they completed a quality of life questionnaire and an acromegaly-specific symptom questionnaire (9). Right hand volume was measured and ring size was measured at the right ring finger using standard jeweler's rings. An i.v. bolus of thyrotropin-releasing hormone (TRH; $200 \mu \mathrm{g}$; Ferring Pharmaceuticals, Tarrytown, NY, USA) was administered at $2100 \mathrm{~h}$ and blood samples for plasma $\mathrm{GH}$ were obtained every $20 \mathrm{~min}$, at baseline and until $2300 \mathrm{~h}$. Blood samples for prolactin were also obtained every $30 \mathrm{~min}$ from $2100 \mathrm{~h}$ until $2300 \mathrm{~h}$. On day 2, subjects underwent 24-h blood sampling for GH every $20 \mathrm{~min}$ (0700-0700 h). On day 3, at $0700 \mathrm{~h}$, blood samples were drawn for serum IGF-I level, free testosterone level and fasting lipid profile (total cholesterol, triglycerides, high density lipoprotein (HDL) cholesterol). Six subjects underwent an oral glucose tolerance test (OGTT) with administration of $100 \mathrm{~g}$ glucose orally at $0700 \mathrm{~h}$ on day 3 with blood samples obtained from $0700 \mathrm{~h}$ until $0900 \mathrm{~h}$, every $20 \mathrm{~min}$ for plasma $\mathrm{GH}$, and every $30 \mathrm{~min}$ for glucose and insulin levels. An i.v. bolus of GH-releasing hormone (GHRH)-44 (1 $\mu \mathrm{g} / \mathrm{kg}$ body weight; Bachem, Torrance, CA, USA) was administered at $1000 \mathrm{~h}$ on day 3 and blood samples for plasma
GH were obtained every $20 \mathrm{~min}$ from $1000 \mathrm{~h}$ until $1200 \mathrm{~h}$. Lights were turned off from $2300 \mathrm{~h}$ until $0700 \mathrm{~h}$ every night and no napping was allowed during daytime. All protocol procedures were repeated at the end of the treatment period with raloxifene. To minimize the risk of thromboembolism all subjects were required to ambulate at least once every $2 \mathrm{~h}$ during daytime. Returned pills were counted at the time of the second admission to assess compliance with the raloxifene regimen.

\section{Assays}

Plasma GH was measured by a chemiluminometric assay with a sensitivity of $0.01 \mu \mathrm{g} / \mathrm{l}$, and intra-assay coefficient of variation (CV) less than 10\% (Nichols Institute Diagnostics, San Juan Capistrano, CA, USA). Plasma IGF-I was measured by a two-site immunoradiometric assay (Diagnostic Systems Laboratories, Webster, TX, USA). Age- and gender-adjusted normal ranges were used. The intra-assay $\mathrm{CV}$ is $4 \%$. Prolactin was measured by a chemiluminometric assay (OrthoClinical Diagnostics, Amersham, Bucks, UK) with a normal range of $3-23 \mathrm{ng} / \mathrm{ml}$ and intra-assay $\mathrm{CV} 6 \%$. Insulin was measured by a chemiluminometric assay (Diagnostic Products Corporation, Los Angeles, CA, USA) with a sensitivity of $2 \mu \mathrm{U} / \mathrm{ml}$ and intra-assay CV of $4 \%$. Free testosterone was measured by a radioimmunoassay (Diagnostic Products Corporation) with a normal range of $10-30 \mathrm{pg} / \mathrm{ml}$ and intra-assay $\mathrm{CV}$ of less than $10 \%$. Lipid levels were measured by the Clinical Pathology Laboratory of the University of Michigan using commercial methods.

For all assays, all samples from each subject were run in the same assay to minimize variability of the measurements. Glucose was measured by Beckman analyzer.

\section{Data analysis}

The 24-h mean GH was calculated as the average of the plasma GH values over $24 \mathrm{~h}$. The GH response to TRH, GHRH and OGTT and the prolactin response to TRH were calculated as the area under the curve (AUC) of $\mathrm{GH}$ vs time using the trapezoidal rule. The serum IGF-I values were expressed both as absolute values and as the ratio to the gender- and age-specific upper normal limit (UNL). Changes in clinical parameters, mean GH values and serum IGF-I levels as well as the GH responses to TRH, GHRH and OGTT before and after treatment with raloxifene were compared by paired $t$-tests after logarithmic transformation of the data where appropriate. The results are presented as means \pm S.E.

\section{Results}

\section{Clinical parameters}

Administration of raloxifene did not result in changes in hand volume or finger size. There was also no 
improvement of any symptoms, including headache, perspiration, arthralgias, fatigue and soft-tissue swelling as assessed by the self-administered questionnaire (data not shown). Raloxifene was well tolerated by all subjects. Specifically, no changes in sexual function were reported.

\section{Serum IGF-I and 24-h mean GH}

During treatment with raloxifene, serum IGF-I decreased in all subjects by an average of $16 \pm 4 \%$ $(520 \pm 80$ vs $604 \pm 72 \mu \mathrm{g} / \mathrm{l}, \quad P=0.0011)$. When serum IGF-I values were expressed as the ratio to the UNL, the results were similar $(1.68 \pm 0.27$ vs $1.94 \pm 0.25, P=0.0006)$. Serum IGF-I normalized in two of the eight subjects (Fig. 1).

Mean GH remained unchanged during raloxifene treatment $(2.4 \pm 0.5 \mathrm{vs} 2.7 \pm 0.9 \mu \mathrm{g} / \mathrm{l}, P=0.56)$ (Fig. 2 ).

\section{TRH and GHRH stimulation tests (Fig. 3)}

The plasma GH responses to i.v. TRH or GHRH were not affected by raloxifene treatment $(P=0.81$ and $P=0.48$ respectively). The baseline serum prolactin concentrations $\quad(12.9 \pm 3.8$ vs $13.1 \pm 3.5 \mathrm{ng} / \mathrm{ml}$, $P=0.52)$, and the prolactin responses to TRH $(P=0.59)$ were unchanged.
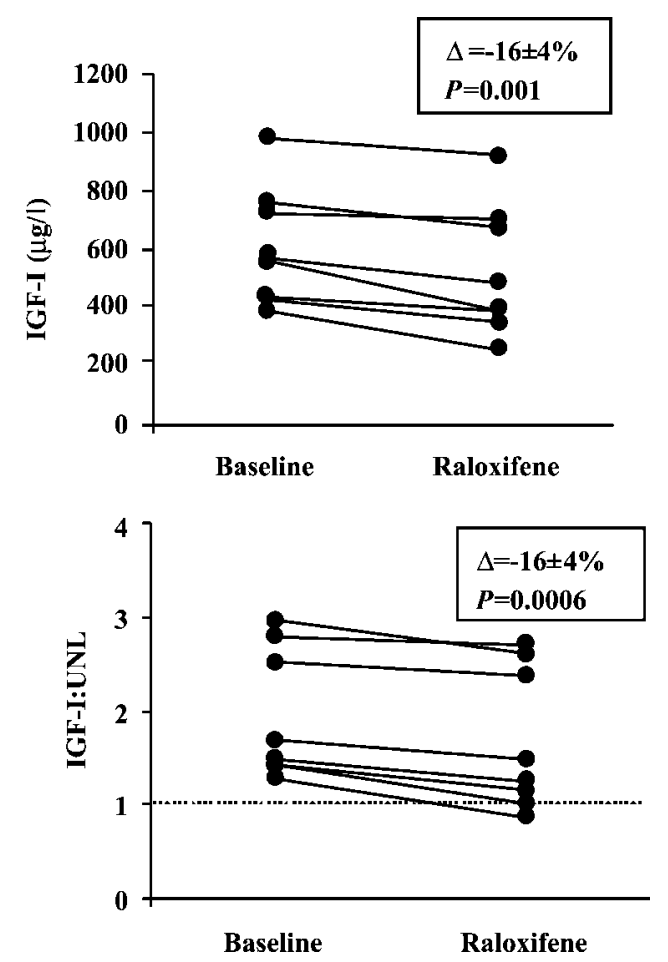

Figure 1 Serum IGF-I levels (upper panel) and ratio of serum IGF-I to the gender- and age-specific UNL (lower panel) before and during treatment with raloxifene.

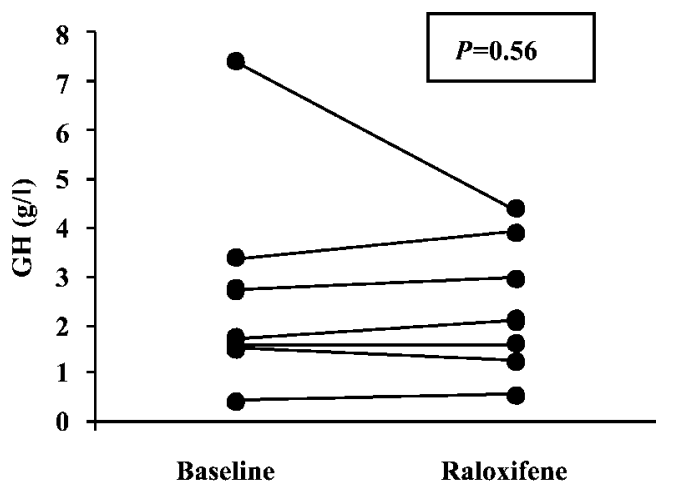

Figure 2 Mean serum GH levels before and during treatment with raloxifene.
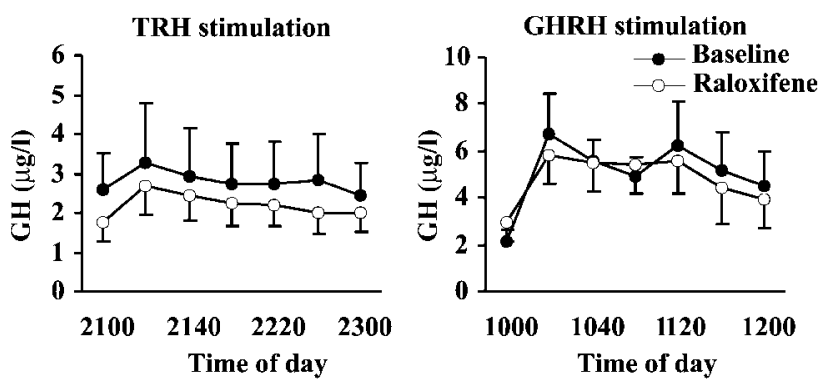

Figure 3 Plasma GH response, presented as means \pm S.E. at each time-point, to TRH and GHRH administration before and during treatment with raloxifene.

\section{OGTT (Fig. 4)}

Fasting blood glucose levels were similar during baseline and raloxifene treatment $(96 \pm 5 \mathrm{vs} 101 \pm 5 \mathrm{mg} / \mathrm{dl}$, $P=0.41)$. The same was true for fasting plasma insulin concentrations $(9.7 \pm 2.7$ vs $10.1 \pm 2.0 \mu \mathrm{U} / \mathrm{ml}$, $P=0.69)$, and fasting insulin to glucose ratio $(P=0.77)$. However, there was an increase in the blood glucose AUC during raloxifene treatment $(20 \pm 6 \%, P=0.015)$. In the entire group, there was no overall change in the insulin responses to the glucose load $(P=0.51)$, but the plasma insulin AUC increased by $47 \pm 23 \%$ in five out of six subjects and decreased by $36 \%$ in one subject. The $\mathrm{GH}$ response to OGTT was not influenced by the treatment with raloxifene $(P=0.89)$.

In the subjects who were not on testosterone replacement therapy $(n=5)$, free testosterone was not affected by treatment with raloxifene $(14.6 \pm 1.8$ vs $19.1 \pm$ $3.5 \mathrm{pg} / \mathrm{ml}, P=0.17)$. Only one of five patients had free testosterone levels below the normal range both before and after treatment with raloxifene. Plasma lipid levels also remained unchanged (data not shown).

\section{Discussion}

Despite the recent progress in the management of acromegaly, there is still a large number of patients who 
OGTT
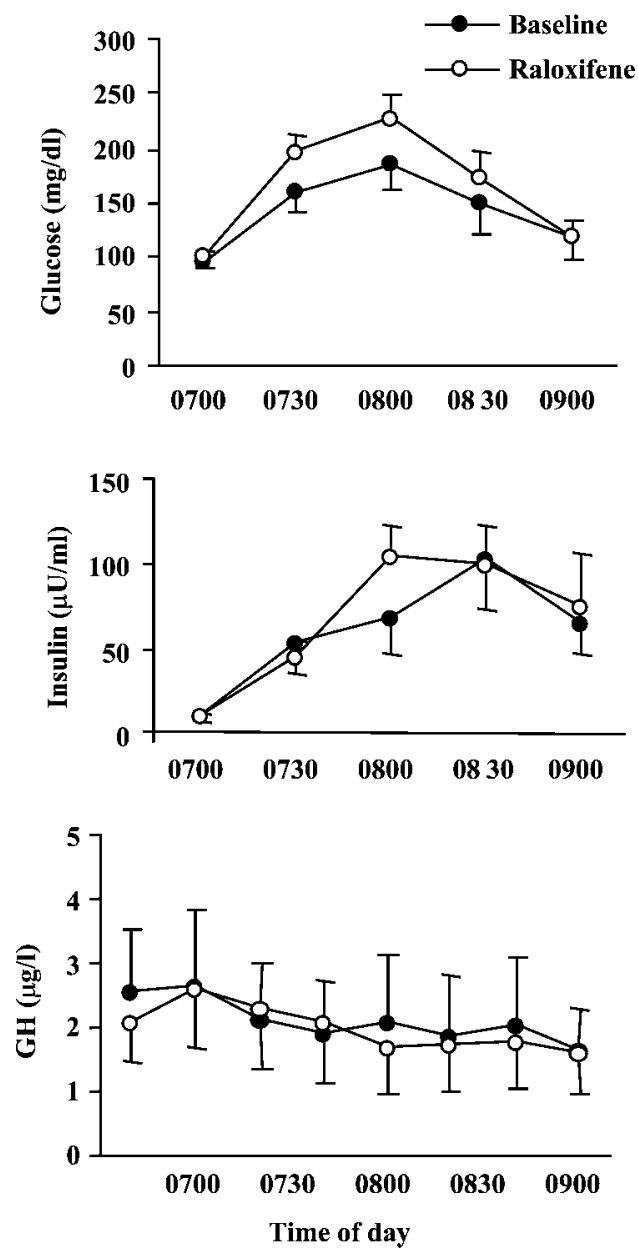

Figure 4 Plasma glucose, insulin and GH after $100 \mathrm{~g}$ oral glucose at $0700 \mathrm{~h}$, before and during treatment with raloxifene. The data are presented as means \pm S.E. at each time-point.

have active disease, defined as the presence of symptoms and elevated plasma IGF-I levels following TSS, radiotherapy or treatment with somatostatin analogs and/or dopamine agonists. The GH antagonist pegvisomant is the most promising and efficacious treatment for acromegaly $(9,10)$. However, the high cost of available medications and the need for parenteral administration of somatostatin analogs and pegvisomant can limit access to treatment.

Pegvisomant blocks GH action on the liver and other peripheral tissues, resulting in normalization of IGF-I in more than $95 \%$ of patients with acromegaly and in clinical improvement $(9,10)$. It is not clear, however, to what extent the clinical improvement can be attributed to the decline in circulating IGF-I or to the direct blockade of GH action on peripheral tissues such as muscle, bone and cartilage. If circulating IGF-I is responsible for most of the clinical manifestations of acromegaly, then suppressing hepatic IGF-I production by other means would be an effective treatment for acromegaly.

In healthy women, oral estrogen suppressed serum IGF-I levels (27) and, in women with GH deficiency, oral estrogen increased $\mathrm{GH}$ requirements to achieve the same level of plasma IGF-I (28). This effect is not mediated through suppression of $\mathrm{GH}$ secretion, since estrogen actually results in increased GH secretion in humans (29). Estrogen could decrease IGF-I production either by directly suppressing IGF-I expression or through suppressing GH receptor (GHR) expression. In rabbits, estrogen inhibits hepatic IGF-I production by inhibiting the expression of the GHR gene (30).

SERMs also suppress IGF-I secretion. Tamoxifen suppressed plasma IGF-I by $40-50 \%$ in women with breast cancer $(19,31)$, and by $24 \%$ in healthy women (18). Unlike estrogen, tamoxifen may also suppress GH secretion. Tamoxifen reduced GH secretion from cultured human somatotroph adenoma cells (32), and from lamb pituitary cells in vitro (33). In vivo, it decreased $\mathrm{GH}$ secretion in pubertal boys and adult males $(34,35)$, and suppressed the GH response to GHRH stimulation in women in one study (22). Another SERM, droloxifene, also suppressed IGF-I levels in a dose-dependent fashion in women with breast cancer (36).

In acromegaly, men have higher IGF-I levels than women with the same fasting GH levels and women on oral estrogen replacement have even lower IGF-I levels (37). Both oral estrogen and tamoxifen have been tried in patients with acromegaly in an effort to decrease circulating IGF-I levels and improve clinical manifestations. Estrogen administration resulted in improvement in glucose tolerance within days of treatment (13), changes in body composition (23) and, in one study, estrogen decreased hand volume (15). Estrogen did not suppress GH secretion (13), but rather decreased the bioactivity of serum sulfation factor (bioassayable IGF-I) (12). Using a sensitive radioimmunoassay for IGF-I, Clemmons et al. (14) showed that oral ethinyl estradiol decreased immunoreactive IGF-I by $47 \%$ within $48 \mathrm{~h}$ after initiation of treatment in patients with acromegaly, accompanied by decreased phosphate and hydroxyproline clearance and decreased fasting blood glucose.

In one study, tamoxifen decreased circulating IGF-I levels by $18-60 \%$ in 13 out of 19 patients with acromegaly, and normalized IGF-I in three patients (17). There was a small increase in GH levels (16). Therefore, like estrogen, tamoxifen primarily inhibited hepatic production of IGF-I.

The effects of raloxifene on the liver and the production of IGF-I are qualitatively similar to these of estrogen and tamoxifen. Raloxifene decreased plasma IGF-I and the response of IGF-I to exogenous $\mathrm{GH}$ stimulation in postmenopausal women $(25,26$, 38 ). In one recent study, 13 women with acromegaly 
received raloxifene (60 mg daily) for 1-12 months (24). IGF-I was suppressed by more than $30 \%$ in ten out of 13 patients, and in some patients this was accompanied by a decrease in ring size.

Whereas estrogen cannot be used in men with acromegaly because of predictable adverse effects such as gynecomastia, decreased libido and erectile dysfunction, the theoretical absence of these adverse effects with raloxifene makes this medication a potential means of decreasing IGF-I levels in male patients with active acromegaly. We have shown that raloxifene induced a small but significant decrease in plasma IGF-I and was able to normalize IGF-I in two out of eight male patients with treatment-resistant acromegaly, without influencing GH secretion and without causing gynecomastia, changes in libido or erectile dysfunction. We did not observe any clinical improvement of the acromegalic syndrome in these patients. The effects of raloxifene on our patients were less pronounced than in female patients. It is possible that our patients responded less because they were men, or because they were treated for a shorter period. The lack of improvement in clinical parameters in our subjects might also be due to the shorter period of treatment.

The degree of IGF-I suppression observed in this study is also lower than the suppression of IGF-I by estrogen or other SERMs $(14,16,36)$, but similar to the suppression of IGF-I by raloxifene in postmenopausal women (26). In a recent study (39) it was shown that raloxifene was less effective than estradiol in suppressing IGF-I in GH-deficient and postmenopausal women. Treatment of postmenopausal women with a large dose of raloxifene $(600 \mathrm{mg} /$ day $)$ did not have any additional effect on IGF-I (26). Therefore, treatment with higher doses would be unlikely to benefit our patients with acromegaly.

The clinical significance of decreasing circulating IGF-I without suppressing GH secretion is unclear. Oral estrogen and the $\mathrm{GH}$ antagonist result in clinical improvement of acromegaly despite the increase in circulating GH levels $(9,15)$. Serum IGF-I is a reliable marker of the response to surgery, radiation therapy or octreotide treatment in acromegaly, as it reflects the suppression of $\mathrm{GH}$ output from the pituitary tumor. In the case of the GH antagonist, serum IGF-I is the only marker of response to treatment, but it is an index of the blockade of GHRs not only in the liver but also at other tissues, such as muscle and bone. Therefore, raloxifene would be effective if circulating IGF-I of hepatic origin is responsible for the majority of acromegaly manifestations or if raloxifene is able to antagonize GH and suppress IGF-I production in other peripheral tissues in addition to the liver.

Although raloxifene exerted an estrogen-like effect on the pituitary by increasing prolactin and suppressing gonadotropins in rats $(40,41)$, in our patients the prolactin response to $\mathrm{TRH}$ stimulation and the serum testosterone levels remained unaffected, suggesting the absence of a significant effect of raloxifene on the human pituitary gland.

Our observations on the effects of raloxifene on glucose and insulin levels are of interest, since they suggest a decrease in insulin sensitivity. This is in contrast to the results of other studies $(24,25,38$, $42,43)$. It is possible that the decrease in insulin sensitivity in our study was due to the higher doses of raloxifene, the shorter period of treatment or the gender of patients.

We have concluded that raloxifene had a mild but significant suppressive effect on IGF-I that is of unclear clinical significance in patients with acromegaly. A therapeutic trial of raloxifene may be justifiable if other, more effective, measures to control active acromegaly are either not tolerated or not available, especially in patients with mildly elevated plasma IGF-I concentrations and mild clinical symptoms. Raloxifene should be given with caution in patients with diabetes mellitus or impaired glucose tolerance since there is a possibility it could worsen insulin sensitivity. The design of new SERMs with estrogenlike activity at the hepatic level and anti-estrogenic effect at the pituitary level might result in a more effective second line treatment for acromegaly. Further studies of the effect of estrogen and SERMs on the expression of IGF-I in the non-hepatic tissues would be valuable.

\section{Acknowledgements}

This work was supported by the Lilly Pituitary Scholars Fellowship (to E V D), the VA Medical Research Service Merit Award (to A L B) and GCRC grant no. M01-RR00042.

\section{References}

1 Melmed S, Ho K, Klibanski A, Reichlin S \& Thorner M. Clinical review 75: Recent advances in pathogenesis, diagnosis, and management of acromegaly. Journal of Clinical Endocrinology and Metabolism 199580 3395-3402.

2 Barkan AL, Halasz I, Dornfeld KJ, Jaffe CA, Friberg RD, Chandler WF et al. Pituitary irradiation is ineffective in normalizing plasma insulin-like growth factor I in patients with acromegaly (see comments). Journal of Clinical Endocrinology and Metabolism 199782 3187-3191.

3 Vance ML \& Harris AG. Long-term treatment of 189 acromegalic patients with the somatostatin analog octreotide. Results of the International Multicenter Acromegaly Study Group. Archives of Internal Medicine $1991 \mathbf{1 5 1} 1573-1578$.

4 Abs R, Verhelst J, Maiter D, Van Acker K, Nobels F, Coolens JL et al. Cabergoline in the treatment of acromegaly: a study in 64 patients. Journal of Clinical Endocrinology and Metabolism 1998 83 374-378.

5 Dimaraki EV, Jaffe CA, DeMott-Friberg R, Chandler WF \& Barkan AL. Acromegaly with apparently normal GH secretion: implications for diagnosis and follow-up. Journal of Clinical Endocrinology and Metabolism 200287 3537-3542. 
6 Clemmons DR \& Underwood LE. Somatomedin-C/insulin-like growth factor I in acromegaly. Journal of Clinical Endocrinology and Metabolism 198615 629-653.

7 Freda PU, Post KD, Powell JS \& Wardlaw SL. Evaluation of disease status with sensitive measures of growth hormone secretion in 60 postoperative patients with acromegaly. Journal of Clinical Endocrinology and Metabolism $1998 \mathbf{8 3}$ 3808-3816.

8 Giustina A, Barkan A, Casanueva FF, Cavagnini F, Frohman L, Ho K et al. Criteria for cure of acromegaly: a consensus statement. Journal of Clinical Endocrinology and Metabolism 200085 526-529.

9 Trainer PJ, Drake WM, Katznelson L, Freda PU, Herman-Bonert V, van der Lely AJ et al. Treatment of acromegaly with the growth hormone-receptor antagonist pegvisomant. New England Journal of Medicine $20003 \mathbf{3 4 2} 1171-1177$.

10 van der Lely AJ, Hutson RK, Trainer PJ, Besser GM, Barkan AL, Katznelson L et al. Long-term treatment of acromegaly with pegvisomant, a growth hormone receptor antagonist. Lancet $20013581754-1759$.

11 Lamberts SW, de Quijada M \& Klijn JG. The effect of tamoxifen on GH and PRL secretion by human pituitary tumors. Journal of Endocrinological Investigation 19803 343-347.

12 Wiedemann E \& Schwartz E. Suppression of growth hormonedependent human serum sulfation factor by estrogen. Journal of Clinical Endocrinology and Metabolism $1972 \mathbf{3 4} 51-58$.

13 Mintz DH, Finster JL \& Josimovich JB. Effect of estrogen therapy on carbohydrate metabolism in acromegaly. Journal of Clinical Endocrinology and Metabolism 196727 1321-1327.

14 Clemmons DR, Underwood LE, Ridgway EC, Kliman B, Kjellberg RN \& Van Wyk JJ. Estradiol treatment of acromegaly. Reduction of immunoreactive somatomedin-C and improvement in metabolic status. American Journal of Medicine $198069571-575$.

15 McCullagh EP, Beck JC \& Schaffenburg CA. Control of diabetes and other features of acromegaly following treatment with estrogens. Diabetes $1955413-23$.

16 Cozzi R, Attanasio R, Oppizzi G, Orlandi P, Giustina A, Lodrini S et al. Effects of tamoxifen on GH and IGF-I levels in acromegaly. Journal of Endocrinological Investigation 199720 445-451.

17 Krattenmacher R, Knauthe R, Parczyk K. Walker A, Hilgenfeldt U \& Fritzemeier KH. Estrogen action on hepatic synthesis of angiotensinogen and IGF-I: direct and indirect estrogen effects. Journal of Steroid Biochemistry and Molecular Biology $1994 \mathbf{4 8}$ 207-214.

18 Decensi A, Robertson C, Ballardini B, Paggi D, GuerrieriGonzaga A, Bonanni B et al. Effect of tamoxifen on lipoprotein(a) and insulin-like growth factor-I (IGF-I) in healthy women. European Journal of Cancer 199935 596-600.

19 Corsello SM, Rota CA, Putignano P, Della Casa S, Barnabei A, Migneco MG et al. Effect of acute and chronic administration of tamoxifen on GH response to GHRH and on IGF-I serum levels in women with breast cancer. European Journal of Endocrinology $1998139309-313$.

20 Huynh H \& Pollak M. Enhancement of tamoxifen-induced suppression of insulin-like growth factor I gene expression and serum level by a somatostatin analogue. Biochemical and Biophysical Research Communications 1994203 253-259.

21 Murphy LJ \& Friesen HG. Differential effects of estrogen and growth hormone on uterine and hepatic insulin-like growth factor I gene expression in the ovariectomized hypophysectomized rat. Endocrinology 1988122 325-332.

22 De Marinis L, Mancini A, Izzi D, Bianchi A, Giampietro A, Fusco A et al. Inhibitory action on GHRH-induced GH secretion of chronic tamoxifen treatment in breast cancer. Clinical Endocrinology 2000 $52681-685$.

23 Nugent AG, Gibney J, Johannsson G, Ng WI, Leung KC \& Ho KY. Treatment of acromegaly with oral estrogen. Proceedings of the 85th Annual Meeting of the Endocrine Society, Phiadelphia, PA 2003 P1-P638.

24 Attanasio R, Barausse M \& Cozzi R. Raloxifene lowers IGF-I levels in acromegalic women. European Journal of Endocrinology 2003 $148443-448$.
25 Oleksik AM, Duong T, Pliester N, Asma G, Popp-Snijders C \& Lips P. Effects of the selective estrogen receptor modulator, raloxifene, on the somatotropic axis and insulin-glucose homeostasis. Journal of Clinical Endocrinology and Metabolism $2001 \mathbf{8 6}$ 2763-2768.

26 Torrisi R, Baglietto L, Johansson H, Veronesi G, Bonanni B, Guerrieri-Gonzaga A et al. Effect of raloxifene on IGF-I and IGFBP-3 in postmenopausal women with breast cancer. British Journal of Cancer 200185 1838-1841.

27 Weissberger AJ, Ho KK \& Lazarus L. Contrasting effects of oral and transdermal routes of estrogen replacement therapy on 24-hour growth hormone $(\mathrm{GH})$ secretion, insulin-like growth factor I, and GH-binding protein in postmenopausal women. Journal of Clinical Endocrinology and Metabolism 199172 374-381.

28 Cook DM, Ludlam WH \& Cook MB. Route of estrogen administration helps to determine growth hormone $(\mathrm{GH})$ replacement dose in GH-deficient adults. Journal of Clinical Endocrinology and Metabolism 199984 3956-3960.

29 Friend KE, Hartman ML, Pezzoli SS, Clasey JL \& Thorner MO. Both oral and transdermal estrogen increase growth hormone release in postmenopausal women - a clinical research center study. Journal of Clinical Endocrinology and Metabolism $1996 \mathbf{8 1}$ $2250-2256$.

30 Domene HM, Marin G, Sztein J, Yu YM, Baron J \& Cassorla FG. Estradiol inhibits growth hormone receptor gene expression in rabbit liver. Molecular and Cellular Endocrinology $1994 \mathbf{1 0 3}$ $81-87$.

31 Ho GH, Ji CY, Phang BH, Lee KO, Soo KC \& Ng EH. Tamoxifen alters levels of serum insulin-like growth factors and binding proteins in postmenopausal breast cancer patients: a prospective paired cohort study. Annals of Surgical Oncology $19985361-367$.

32 Giustina A, Bollati A, Bonfanti C, Licini M, Ragni G, Misitano V et al. Effects of estrogen receptor modulation by tamoxifen on growth hormone secretion in cultured human GH secreting pituitary adenoma cells. Journal of Endocrinological Investigation 1996 19 (Suppl to no. 5), Abstract 107, p 130.

33 Malaab SA, Pollak MN \& Goodyer CG. Direct effects of tamoxifen on growth hormone secretion by pituitary cells in vitro. European Journal of Cancer 1992 28A 788-793.

34 Weissberger AJ \& Ho KK. Activation of the somatotropic axis by testosterone in adult males: evidence for the role of aromatization. Journal of Clinical Endocrinology and Metabolism $1993 \mathbf{7 6}$ 1407-1412.

35 Metzger DL \& Kerrigan JR. Estrogen receptor blockade with tamoxifen diminishes growth hormone secretion in boys: evidence for a stimulatory role of endogenous estrogens during male adolescence. Journal of Clinical Endocrinology and Metabolism $199479513-518$.

36 Helle SI, Anker GB, Tally M, Hall K \& Lonning PE. Influence of droloxifene on plasma levels of insulin-like growth factor (IGF)I, Pro-IGF-IIE, insulin-like growth factor binding protein (IGFBP)-1 and IGFBP-3 in breast cancer patients. Journal of Steroid Biochemistry and Molecular Biology 199657 167-171.

37 Parkinson C, Ryder WD \& Trainer PJ. The relationship between serum GH and serum IGF-I in acromegaly is gender-specific. Journal of Clinical Endocrinology and Metabolism $2001865240-5244$.

38 Andersson B, Johannsson G, Holm G, Bengtsson BA, Sashegyi A, Pavo I et al. Raloxifene does not affect insulin sensitivity or glycemic control in postmenopausal women with type 2 diabetes mellitus: a randomized clinical trial. Journal of Clinical Endocrinology and Metabolism $2002 \mathbf{8 7} 122-128$.

39 Gibney J, Johannsson G, Leung KC \& Ho KY. Comparison of the metabolic effects of oral estrogen and raloxifene in post-menopausal and GH-deficient women. Proceedings of the 85th Meeting of the Endocrine Society, Philadelphia, PA 2003 P2-P367.

40 Pinilla L, Gonzalez LC, Tena-Sempere M \& Aguilar E. Evidence for an estrogen-like action of raloxifene upon the hypothalamic-pituitary unit: raloxifene inhibits luteinizing hormone secretion and stimulates prolactin secretion in ovariectomized female rats. Neuroscience Letters 2001311 149-152. 
41 Neubauer BL, Best KL, Clemens JA, Gates CA, Goode RL, Jones CD et al. Endocrine and antiprostatic effects of raloxifene (LY156758) in the male rat. Prostate 199323 245-262.

42 Cucinelli F, Soranna L, Romualdi D, Muzj G, Mancuso S \& Lanzone A. The effect of raloxifene on glyco-insulinemic homeostasis in healthy postmenopausal women: a randomized placebo-controlled study. Journal of Clinical Endocrinology and Metabolism 200287 4186-4192.
43 Cagnacci A, Paoletti AM, Zanni A, Arangino S, Ibba G, Orru M et al. Raloxifene does not modify insulin sensitivity and glucose metabolism in postmenopausal women. Journal of Clinical Endocrinology and Metabolism 200287 4117-4121.

Received 4 September 2003

Accepted 11 December 2003 